\title{
Attracting and Pushing Factors in International Migration Exchange Between Russia and the Post-Soviet Countries Within the Framework of the Concept of Sustainable Development
}

\author{
Marina Zhukova, Lidiya Manukovskaya, Larisa Kharyanova*, Yulia Lobanova
}

\author{
Altai State University, Barnaul, Russia \\ ${ }^{*}$ Corresponding author. Email: harjanova@rb.asu.ru
}

\begin{abstract}
The authors consider the importance of migration in ensuring the country's sustainable development. The influence of migration on the average annual population of the Russian Federation is studied. The article deals with the migration exchange between Russia and the post-Soviet countries: Armenia, Kazakhstan, Kyrgyzstan, Tajikistan, Uzbekistan, etc. The authors consider the impact of the COVID-19 pandemic on changes in migration processes between Russia and the post-Soviet countries. The study of the relationship between indicators of migration exchange between Russia and the post-Soviet countries and socio-economic indicators of the Russian Federation was carried out using SPSS 20 based on the pair correlation method. The analysis of interrelations revealed a strong correlation of socio-economic indicators with indicators of migration exchange between the Russian Federation and the post-Soviet countries, which made it possible to identify the attracting and pushing factors of migration. The results of the study can be used in the development of the migration policy of the Russian Federation to ensure its sustainable development.
\end{abstract}

Keywords: factors in international migration, sustainable development, migration exchange.

\section{INTRODUCTION}

The problems of sustainable development of the Russian Federation are becoming a priority at the current stage of the country's development. The current understanding of sustainable development began to take shape in 1983, when the UN convened the World Commission on Environment and Development, called the Commission Brundtland. The term "sustainable development" was approved by the Commission in 1987t. Thus, sustainable development is a set of measures aimed at meeting current human needs while preserving the environment and resources, that is, without compromising the ability of future generations to meet their own needs [1].

In 2015, all UN member States adopted 17 Sustainable Development Goals as part of the 2030 Agenda for Sustainable Development [2].

The 2030 Agenda for Sustainable Development recognizes the positive contribution of migration processes to sustainable development. Eleven out of 17 goals contain tasks and indicators that are applicable to migration and mobility.

Consequently, international migration plays an important role in ensuring sustainable development of Russia.

The average annual population of the Russian Federation in 2020 decreased by 304852 people compared to 2019. In 2010-2011 and in 2016-2019, there was a natural decline in the population, that is, the number of deaths exceeded the number of births. Despite this, the population of the Russian Federation since 2010-2019 did not decrease, but increased due to migration growth of the population.

However, in 2020, the coefficient of natural population loss was $(-4.4) \%$, and the migration growth, although positive, could not compensate for it, which led to a decrease in the population of the Russian Federation. Birth rates have gradually declined in the Russian Federation from $13.4 \%$ in 2015 to $9.9 \%$ in 2020. Mortality rates have also decreased from $12.6 \%$ in 2016 to $11.9 \%$ in 2019 . In 2020 , the mortality rate in 
the Russian Federation increased by $2.4 \%$ compared to 2019 and amounted to $14.6 \%$, primarily due to the impact of the COVID-19 pandemic.

Over the period of 2010-2021, the working-age population of the Russian Federation has decreased by 6.102 million people, and its share has decreased from $61.59 \%$ to $56.02 \%$ of the total population. As reported by Bloomberg agency, the labor shortage in Russia slows down the recovery of the country's economy after the pandemic [3].

At present, migration has become a real mechanism of economic integration between the Russian Federation and the post-Soviet countries. There is a significant migration exchange between Russia and Armenia, Kazakhstan, Kyrgyzstan, Tajikistan, Uzbekistan, and Ukraine.

Migration of the population from the post-Soviet countries plays an important role in the development of the Russian economy. Population migration can contribute to the revival and development of such industries as construction, transport, agriculture and trade. Consequently, migration is an important element of ensuring the sustainable development of the Russian Federation.

In the future, the Russian Federation may experience a shortage of specialists, the intellectual potential of the country will decrease, which in general will adversely affect its socio-economic development. Therefore, we consider it appropriate to conduct research of factors influencing migration exchange between the Russian Federation and post-Soviet countries.

\section{MATERIALS AND METHODS}

The works of domestic and foreign authors: Li E. [4], E. S. Vakulenko, N. V. Mkrtchyan, K. K. Furmanov [5], E. Fong [6], Yu. A. Logunova [7], R.Ramos [8], S. V.Taskaeva [9], A. A. Tkachenko [10], P. G.Abdulmanapov [11], R. Bhagat [12] and V. I. Perevedentsev [13] are devoted to studying the influence of socio-economic indicators of the country's development on the processes of population migration.

There are various approaches to systematization of population migration factors. V. I. Perevedentsev divides all migration factors into objective and social ones [13].

G. S. Vechkanov suggests dividing migration factors into social and economic ones. Social factors include: the level of development of social infrastructure (education, health care, and culture), the contents and nature of work, and so on [14].

Edward $\mathrm{Li}$ identified the following factors influencing migration processes: retaining, attracting, and pushing factors [4].
In our research, we will focus on identifying the attracting and pushing factors that influence the migration exchange of the Russian Federation with the post-Soviet countries.

The following indicators were selected as significant attracting and pushing factors: the subsistence minimum, the average pension size, the ratio of the average pension size to the subsistence minimum, the average monthly nominal salary, its ratio to the subsistence minimum, the unemployment rate, GDP per capita, consumer price index, foreign trade turnover, industrial production, gross agricultural output, commissioning of residential buildings, government spending on education and health, the average annual exchange rate of the national currency to the US dollar, and others.

The main purpose of this paper is to study the relationship between the net migration rate of Russia in exchange with the post-Soviet countries and socioeconomic indicators of the Russian Federation. For this purpose, we used official statistical data for Russia and the post-Soviet countries: Armenia, Kazakhstan, Kyrgyzstan, Uzbekistan, Tajikistan, and Ukraine for the period from 2010 to $2020[15,16]$.

The analysis of the indicators was carried out based on the data presented on the official websites of the Committee on Statistics of the Ministry of National Economy of the Republic of Kazakhstan and the official website of the Federal Statistics Service of the Russian Federation $[14,15]$.

When processing empirical data, the following results were obtained: the Pearson correlation coefficient $r$, the number of pairs of values used, and the probability of error. Analysis of the relationship between the net migration rate of Russia in exchange with the post-Soviet countries and socio-economic indicators was carried out using SPSS 20.0 by means of the pair correlation method. In order to evaluate the criterion of the relationship between variables as well as analyze the strength of the relationship, statistical tools were used: correlation coefficient (r) and significance level (p).

The tightness of the relationship is determined using the correlation coefficient, which can have a value from "minus" 1 to "plus" 1. For the direct relationship between indicators, the correlation coefficient is more than 0 , and for the inverse relationship, it is less than 0 . The larger the absolute value of the correlation coefficient, the closer the relationship between the indicators is. If the value of the correlation coefficient lies in the range of more than 0.9 modulo, it means that there is very strong correlation dependence. If the value of the correlation coefficient lies in the range up to 0.9 modulo the average one, up to 0.5 denotes a weak one, and finally up to 0.2 shows weak correlation 
dependence or its complete absence. The degree of significance of the correlation between the studied phenomena is set by certain threshold values [17].

For practical purposes of this study, we used a correlation threshold value of 0.6 and a significant significance level $(p<0.05)$.

\section{RESULTS AND DISCUSSION}

Let us consider the migration situation in the Russian Federation within the period 2010-2020.

In the analyzed period, the net migration rate has positive values, that is, the inflow of migrants exceeds the outflow of citizens from the Russian Federation. The values of the net migration rate are undulating. A significant increase in this indicator was observed in 2010-2011 (by 1.3\%o) and 2018-2019 (by 1.09\%). In 2011-2015, 2016-2017, and 2019-2020, the net migration rate declined. In 2019-2020, the decline in this indicator was $1.21 \%$, which should be explained by the impact of the global COVID-19 pandemic and related restrictive measures.

In 2010-2020, the structure of arrivals is dominated by citizens coming from Ukraine (22.39\%), followed by citizens of Kazakhstan (11.49\%), citizens of Uzbekistan (13.98\%), citizens of Tajikistan (10.86\%). The share of citizens arriving from Ukraine, Kazakhstan, Uzbekistan, Tajikistan, Armenia and Kyrgyzstan in the total number of citizens arriving in the Russian Federation is $74.34 \%$.

The structure of departures is dominated by citizens leaving for Ukraine (19.4\%), Uzbekistan (16.02\%), Kazakhstan $(9.86 \%)$, and Tajikistan $(9.33 \%)$. The share of citizens who left for Ukraine, Kazakhstan, Uzbekistan, Tajikistan, Armenia and Kyrgyzstan in the total number of citizens who left the Russian Federation in $2010-2020$ is $69.76 \%$.

The analysis of the dynamics in the number of citizens arriving in the Russian Federation from the countries under study allowed us to draw the following conclusions:

In 2010-2014, Uzbekistan was the leader in terms of the number of citizens who arrived in the Russian Federation. In 2015-2020, the number of citizens arriving from Uzbekistan significantly decreased compared to 2013-2014.

In 2015, the migration situation changed: in 20152020 , the largest migration inflow was provided by Ukrainian citizens. In 2010-2015, the number of citizens arriving from Ukraine in the Russian Federation increased by 7.06 times. In the period of 2015-2018, this indicator decreased by $29.05 \%$. In $2015-2020$, more than 137,000 citizens annually came to Russia from Ukraine.
In 2010-2019, the number of citizens arriving from Kazakhstan to Russia increased by 3.1 times, and the number of citizens arriving from Armenia to Russia increased by 3.62 times.

The increase in the number of migrants from Tajikistan to the Russian Federation for the period of 2010-2020 was $413.17 \%$.

The most significant inflow of citizens from the studied countries to the Russian Federation was in 2019 and amounted to 523,805 people.

In 2020, compared to 2019, there is a decrease in the number of arrivals from Ukraine, Kazakhstan, Uzbekistan, Kyrgyzstan and Armenia. The total decrease in the number of arrivals of citizens from the studied countries to the Russian Federation in 2020 compared to 2019 was $13.29 \%$. This may also be due to the COVID-19 pandemic, which has led to restrictive measures and the closure of state borders.

Analysis of the dynamics in the number of citizens who left the Russian Federation to the post-Soviet countries allowed us to reveal a number of trends:

From 2010-2018, there was an increase of 19.58 times in the number of citizens who left the Russian Federation for Ukraine. In 2018-2020, there was a reduction in citizens who left Russia for Ukraine.

From 2010-2015, Uzbekistan was the leader in terms of the number of citizens who left the Russian Federation, and from 2015-2020, Ukraine took the first place in terms of the number of citizens who left the Russian Federation.

For the period 2010-2020, the number of citizens who left the Russian Federation for Armenia increased by 83.6 times, to Kazakhstan by 7.65 times, to Kyrgyzstan by 69.07 times, to Tajikistan by 77.69 times, to Uzbekistan by 54.28 times, to Ukraine by 14.53 times.

In 2019-2020, in the studied countries there was an increase in the number of citizens who left the Russian Federation, with the exception of Ukraine. Hundreds of thousands of migrants were forced to leave Russia due to the coronavirus. In total, the number of citizens who left the Russian Federation for these countries increased by $15.33 \%$ in 2020 compared to 2019 .

Based on the data presented in Figure 1, a number of conclusions can be drawn:

In 2010-2020, migration growth of Russia in the exchange with all the countries studied was positive, with the exception of Uzbekistan in 2015 (migration decline was 20,668 people), and Armenia in 2020 (migration decline was 1,844 people).

The largest contribution to migration growth of Russia in 2010-2013 was made by Uzbekistan, in 2014- 




Figure 1 Migration growth of the Russian Federation in exchange with the countries of the former Soviet Union within 2010-2020, people

2017 and 2019-2020 by Ukraine. Kazakhstan also plays an important role in the migration growth of the Russian Federation. The same can be said about Tajikistan in 2016-2020.

In 2019-2020, the total amount of migration growth of the Russian Federation due to the migration exchange with the studied countries decreased by $52.47 \%$ and amounted to 105,105 people in 2020. One of the most significant reasons for this situation is the COVID-19 pandemic, and the associated restrictive measures and job losses.

The results of the correlation analysis

1. Let us consider the results of the correlation analysis of the net migration rate and socio-economic indicators of Russia.

When analyzing the relationship, the opposite correlation was found between the net migration rate in Russia and the socio-economic indicator "the share of children and adolescents under the age of 18 permanently residing in Russia", \% $(r=-0.617 * ; p=$ 0.043).

It should be noted that since 2011, the decrease in the net migration rate coincides with the increase in the proportion of children, and in 2019 the situation changes to the opposite. The negative relationship between the share of children indicator and the migration growth of the Russian Federation in exchange with foreign countries can be explained by the fact that the population migrates mainly without children in order to find earnings and provide for their families at home.

We also found linear correlations between the net migration rate and the following socio-economic indicators:

- gross agricultural output per capita in US dollars ( $\mathrm{r}$ $=0.684^{*} ; \mathrm{p}=0.020$ );
- the value of the subsistence minimum in US dollars $\left(\mathrm{r}=0.610^{*} ; \mathrm{p}=0.046\right)$.

The increase in the net migration rate can be explained by poorer conditions of economic development of the territory of former residence of migrants according to such socio-economic indicators as gross agricultural output per capita in US dollars and the value of the subsistence minimum in US dollars.

The decrease in the net migration rate means that the population of the post-Soviet countries assesses the development of the Russian economy as unstable according to the following socio-economic indicators: gross agricultural output per capita in US dollars and the cost of living in US dollars and consequently, people search for more economically developed territories.

In other words, the growth of socio-economic indicators "gross agricultural output per capita in US dollars" and the subsistence minimum" is an attracting factor for migration of the population of the post-Soviet countries. In turn, the decline in these socio-economic indicators is a pushing factor for migration.

2. Let us consider the results of the correlation analysis of the net migration rate of Russia in exchange with Armenia and socio-economic indicators.

Net migration rate of Russia in exchange with Armenia was calculated as the ratio of migration growth of the Russian Federation with Armenia multiplied by 1000 to the average annual population of Russia. The growth of Russia in exchange with Armenia is defined as the difference between the number of arrivals to the Russian Federation from Armenia and the number of departures from the Russian Federation to Armenia.

When analyzing the relationship, we revealed the opposite correlations of the net migration rate of Russia in exchange with Armenia and the socio-economic 
indicator "the average annual exchange rate of the US dollar, in the national currency" $(\mathrm{r}=-0.642 * ; \mathrm{p}=$ 0.033 ).

It should be noted that the increase in the average annual exchange rate of the US dollar to the national currency contributes to a decrease in the net migration rate in exchange with Armenia. This relationship is explained by the fact that the growth of the US dollar exchange rate against the rouble negatively affects the economic sector and the social sphere, first of all, by reducing the real incomes of the population.

Consequently, the increase in the average annual exchange rate of the US dollar to the national currency characterizes the deterioration of the population's wellbeing and is a pushing factor for migration of the Armenian population.

We also found significant direct correlations of the net migration rate of Russia in exchange with Armenia and the following socio-economic indicators:

- export per capita, US dollars $\left(\mathrm{r}=0.770^{* *} ; \mathrm{p}=\right.$ 0.006 );

- the subsistence minimum, in US dollars ( $\mathrm{r}=$ $0.710^{*} ; \mathrm{p}=0.014$ );

- GDP per capita, US dollars ( $\left.\mathrm{r}=0.700^{*} ; \mathrm{p}=0.014\right)$;

- investment in fixed assets per capita, US dollars ( $\mathrm{r}$ $=0.668^{*} ; \mathrm{p}=0.025$ );

- foreign trade turnover, US dollars $(\mathrm{r}=0.712 * ; \mathrm{p}=$ $0.014)$;

- gross agricultural output per capita, US dollars (r= $0.664 * ; \mathrm{p}=0.026$ ); $0.040)$.

- import per capita, US dollars $\left(\mathrm{r}=0.625^{*} ; \mathrm{p}=\right.$

The development of the national economy in the country and the improvement of the standard of living of its population is reflected in the growth of the identified socio-economic indicators. Thus, these indicators are characteristics of Russia's economic development and their growth is an attracting factor for the migration of the Armenian population, which in this case assesses the territory of Russia as economically more favorable for living or working.

3. Let us consider the results of the correlation analysis of the net migration rate of Russia in exchange with Kazakhstan and socio-economic indicators.

When analyzing the relationship, we revealed strong opposite correlations of the net migration rate were Russia in exchange with Kazakhstan and socioeconomic indicator-imports as \% of GDP $(r=-0.834 *$; $\mathrm{p}=0.001)$

It should be noted that the observed growth of the socio-economic indicator of Russia "import, as a percentage to GDP" in the context of the growth of the average annual exchange rate of the US dollar against the national currency makes imported goods more expensive, accelerating inflation, which negatively affects the purchasing power of the population. Consequently, in the Russian conditions of economic development, the growth of this socio-economic indicator is a pushing factor for migration of the population of Kazakhstan to Russia [18].

According to the results of the correlation analysis, a strong linear correlation was found between the net migration rate of Russia in exchange with Kazakhstan and the socio-economic indicator of Russia "employed population, in million people" $\left(\mathrm{r}=0.816^{* *} ; \mathrm{p}=0.002\right)$ for the period 2010-2020.

The relationship between economic growth and employment is the No. 1 indicator of economic and social development of the country for the population of Kazakhstan. Due to a long period of economic crisis, Kazakhstan was characterized by long-term unemployment. Therefore, an increase in the level of employment in Russia indicates economic well-being and is an attracting factor for migration of the population of Kazakhstan to Russia [17].

4. Let us consider the results of a correlation analysis of the net migration rate of the Russian Federation in exchange with Kyrgyzstan and socioeconomic indicators of Russia.

When analyzing the relationship, we found opposite correlations between the net migration rate in exchange with Kyrgyzstan and the following socio-economic indicators:

- the average annual exchange rate of the US dollar to the national currency $\left(\mathrm{r}=-0.771^{* *} ; \mathrm{p}=0.005\right)$;

- the number of permanent residents at the end of the year, people $\left(\mathrm{r}=-0.711^{*} ; \mathrm{p}=0.014\right)$.

It should be noted that the growth of the US dollar exchange rate against the rouble negatively affects the level of economic development and the social sphere, first of all, real incomes of the population are reduced. Therefore, it is a pushing factor and has a negative impact on the migration growth of the population of the Russian Federation.

It should be noted that after 2017, there is a clearly defined negative relationship, when an increase in the number of permanent residents in Russia correlates with a decrease in the net migration rate of the Russian Federation in exchange with Kyrgyzstan. This circumstance is primarily due to the fact that during this period, the process of departure of Kyrgyz migrants from Russia began to take place more intensively. This process is most likely related to the return of migrants who have not been able to adapt to the constantly changing socio-economic conditions of Russia. In turn, 
migrants who have earned money in Russia, in most cases, do not return to their country and settle in Russia as a permanent population.

Consequently, the growth of such socio-economic indicators as the commissioning of residential buildings, sq. $m$. of total area and the average annual exchange rate of the US dollar to the national currency should most likely be viewed as pushing factors for migration of the population of Kyrgyzstan to Russia. And the number of permanent residents at the end of the year is a litmus factor that shows changes in the intensity of migration flows of the Kyrgyz population to Russia, as well as the replenishment of the permanent population from among labor migrants.

Further, we identified linear correlations of the net migration rate of the Russian Federation in exchange with Kyrgyzstan and the following socio-economic indicators:

- the cost of living, in US dollars ( $\mathrm{r}=0.701^{*}$; $\mathrm{p}=0.016)$;

- gross agricultural output per capita, US dollars ( $\mathrm{r}=$ $0.644^{*} ; \mathrm{p}=0.032$ );

- investment in fixed assets per capita, US dollars ( $\mathrm{r}$ $=0.623^{*} ; \mathrm{p}=0.041$ );

- GDP per capita, US dollars $\left(r=0.603^{*} ; \mathrm{p}=0.049\right)$; $0.032)$

- foreign trade turnover, US dollars $(\mathrm{r}=0.642 * ; \mathrm{p}=$

- export per capita, US dollars $\left(\mathrm{r}=0.660^{*} ; \mathrm{p}=\right.$ 0.027); $0.040)$.

- import per capita, US dollars $\left(\mathrm{r}=0.623^{*}\right.$; $\mathrm{p}=$

It should be noted that Kyrgyz migrants primarily pursue an economic goal, which is earning money. Therefore, they take into account the peculiarities of the economic state of the territories of the post-Soviet countries attractive for migration, i.e. they are an indicator of the socio-economic state of the host country.

Such socio-economic indicators as: the cost of living, US dollars; gross agricultural output per capita, US dollars; investment in fixed assets per capita, US dollars; GDP per capita, US dollars; foreign trade turnover, US dollars; export per capita, US dollars; import per capita, US dollars reflect the level of development of the national economy in the country and the standard of living of its population. Consequently, these indicators are characteristics of Russia's economic development and their growth is an attracting factor for migration of the population of the Republic of Kyrgyzstan, which in this case assesses the territory of Russia as economically more favorable for working and allows them to support their families at home with money transfers, as well as reduce the number of unemployed in the republic [19].

5. Let us consider the results of a correlation analysis of the net migration rate of the Russian Federation in exchange with Tajikistan and socioeconomic indicators of Russia.

Correlation analysis revealed negative relationships between the net migration rate of the Russian Federation in exchange with Tajikistan and the socio-economic indicator for Russia "the consumer price index compared to the previous year" $(r=-0.694 * ; p=0.018)$ for the period 2010-2020.

The increase in the consumer price index indicator compared to the previous year in Russia is a pushing factor for migration of the population of Tajikistan due to the increase in the consumer price index indicator compared to the previous year indicates an increase in the level of inflation and a decrease in the standard of living of the population, which in its turn creates unattractive conditions for migration.

According to the results of the analysis, significant direct relationships were found between the net migration rate of the Russian Federation in exchange with Tajikistan and socio-economic indicators in Russia: the ratio of the average pension size and the subsistence level in US dollars $\left(r=0.674^{*} ; \mathrm{p}=0.023\right)$, the ratio of the average monthly nominal salary and the subsistence level in US dollars $\left(r=0.676^{*} ; p=0.022\right)$, the share of women in $\%(r=0.652 * ; p=0.030)$ for the period of 2010-2020.

Indicators of the ratio of the average pension size and the subsistence minimum in US dollars, as well as the ratio of the average monthly nominal salary and the subsistence minimum in US dollars are indicators that characterize the well-being of citizens and the entire country as a whole.

Since an increase in the ratio of the average pension size and the subsistence minimum in US dollars, as well as the ratio of the average monthly nominal salary and the subsistence minimum in US dollars, do not indicate an increase in the welfare of citizens in modern Russia, due to the fact that, in contrast to wages and the average pension size, the level of the subsistence minimum in absolute terms has increased to a much lesser extent. According to E. V. Reprintseva, directly appointed subsistence minimum is greatly underestimated, and denotes a standard of very low consumption, so it does not meet the most important human needs of the $21 \mathrm{st}$ century [20].

However, according to the results of the correlation analysis, then increase in the ratio of the average pension size and the subsistence minimum in US dollars, as well as the ratio of the average monthly nominal salary and the subsistence minimum in US 
dollars, is not a pushing factor and affects the increase in migration inflow in exchange with Tajikistan. Probably, this circumstance is connected with the worse conditions of economic development of the territory of Tajikistan.

The share of women in Russia is a litmus factor that shows changes in the characteristics of migration flows of the population from Russia to Tajikistan by gender and indicates until 2018 that the immigration of the population is somewhat more male, and since 2018more female in exchange with Tajikistan.

6. Let us consider the results of a correlation analysis of the net migration rate of the Russian Federation in exchange with Uzbekistan and socioeconomic indicators of Russia.

When analyzing the relationship, we found opposite correlations between the net migration rate of the Russian Federation in exchange with Uzbekistan and the following socio-economic indicators for Russia:

- the average annual exchange rate of the US dollar to the national currency $(\mathrm{r}=-0.784 * * ; \mathrm{p}=0.004)$;

- the number of permanent residents at the end of the year, people $(\mathrm{r}=-0.702 * ; \mathrm{p}=0.016)$.

The growth of the US dollar exchange rate against the ruble has a negative impact on the level of economic development and on the social sphere, first of all, by reducing the real incomes of the population. Therefore, it is a pushing factor that affects the growth of population outflow from the Russian Federation.

It should be noted that after 2013, there is a clearly defined negative relationship, when an increase in the number of permanent residents in Russia correlates with a decrease in the net migration rate Russia in exchange with Uzbekistan. This circumstance is primarily due to the fact that during this period, the process of departure of migrants from Russia began to take place more intensively. This process is most likely related to the return of migrants who have not been able to adapt to the constantly changing socio-economic conditions of Russia. In turn, migrants who have earned a certain fortune in Russia, in most cases, do not return to their country and settle in Russia as a permanent population.

Consequently, the growth of such socio-economic indicators as the commissioning of residential buildings, sq. m. of total area; the average annual exchange rate of the US dollar to the national currency; is rather pushing factors for migration of the population of Uzbekistan to Russia. And the number of permanent residents at the end of the year is a litmus factor that shows changes in the intensity of migration flows of the population of Uzbekistan to Russia, as well as the replenishment of the permanent population from among labor migrants.
According to the results of the analysis, strong direct relationships were found between the net migration rate Russia in exchange with Uzbekistan and the following socio-economic indicators in Russia: gross agricultural output per capita, USD ( $\mathrm{r}=0,903 * * ; \mathrm{p}=0,000)$; investments in fixed capital per capita, USD $(\mathrm{r}=$ $\left.0,896^{* *} ; \mathrm{p}=0,000\right)$; import per capita, USD ( $\mathrm{r}=$ $0,879 * * ; p=0.000)$; the minimum subsistence level, the $\operatorname{USD}\left(\mathrm{r}=0,877^{*} ;, \mathrm{p}=0.000\right)$; the foreign trade turnover by USD $\left(r=0,823^{* *} ; \mathrm{p}=0.002\right)$; export per capita, USD $\left(\mathrm{r}=0,799^{* *} ; \mathrm{p}=0.003\right)$ for the period of $2010-2020$.

The development of the national economy in the country and the standard of living of its population is reflected in the growth of the identified socio-economic indicators. Thus, these indicators are characteristics of Russia's economic development and their growth is an attracting factor for the migration of the population of Uzbekistan, which in this case assesses the territory of Russia as economically more favorable for living or working.

7. Let us consider the results of the correlation analysis of the net migration rate of the Russian Federation in exchange with Ukraine and socioeconomic indicators of Russia.

When analyzing the relationship, we revealed the opposite correlation of the net migration rate of the Russian Federation in exchange with Ukraine and the socio-economic indicator "imports as a percentage to GDP” $\left(r=-0.636^{*} ; \mathrm{p}=0.035\right)$.

It should be noted that the observed growth of the socio-economic indicator of Russia "import as a percentage to GDP" in the context of the growth of the average annual exchange rate of the US dollar against the national currency makes imported goods more expensive, thus accelerating inflation, which negatively affects the purchasing power of the Russian population [20].

However, in the Russian conditions of economic development, the growth of this socio-economic indicator is an attracting factor for the migration Ukrainian population, due to the fact that the purchasing power of a Russian is one and a half times as great as that of a Ukrainian.

We also found linear correlations of the net migration rate of Russia in exchange with Ukraine and the following socio-economic indicators:

- consumer price index compared to the previous year $(\mathrm{r}=0.722 * ; \mathrm{p}=0.012)$;

- commissioning of residential buildings per capita, sq. m. of total area $\left(r=0.680^{*} ; \mathrm{p}=0.021\right)$.

The increase in the consumer price index indicator compared to the previous year in Russia is an attracting factor for migration of the population of Ukraine, 
despite the fact that the increase in the consumer price index indicator compared to the previous year indicates an increase in the level of inflation and a decrease in the standard of living of the Russian population. It should be noted that over the period from 2010 to the present, both the rouble and the hryvnia have significantly fallen in price against the dollar - the Russian currency by 2.5 times, and the Ukrainian currency by 3.4 times. A particularly sharp drop in the price of national currencies occurred in 2014 and 2015. However, the ruble maintained a stronger position, which in turn had a smaller impact on consumer prices and created more attractive living conditions in Russia.

The commissioning of residential buildings per capita, sq. m. of total area is an indicator of availability of housing for the population and one of the most important indicators of the country's successful socioeconomic development and the quality of life of the population.

The maximum increase in the rate of housing commissioned in Russia compared to the previous year's level over the past ten years was observed in 2014 - by $18.2 \%$. Since 2016 , construction rates have decreased by $6.0 \%$, in 2017 - by $1.3 \%$, in 2018 -by $4.5 \%$. In 2019 , the total area of housing commissioned increased by $6.2 \%$, and in 2020 -by $0.2 \%$.

Among the subjects of the Russian Federation in 2020 , the largest volumes of housing construction were carried out in the Moscow Region, where $11.0 \%$ of the total housing area commissioned in Russia as a whole was commissioned, the Krasnodar Territory $-6.2 \%$, Moscow $-6.1 \%$, St. Petersburg- $4.1 \%$, the Republic of Tatarstan $-3.3 \%$, the Leningrad and Rostov Regions $3.2 \%$ each, the Republic of Bashkortostan $-3.0 \%$, the Sverdlovsk Region $-2.9 \%$, the Novosibirsk Region $2.4 \%$, the Voronezh Region $-2.1 \%$, the Tyumen Region (excluding autonomous districts) and Chelyabinsk regions $-1.9 \%$ each. In these regions of the Russian Federation, 42.2 million square meters of total housing area were built [21].

Many of these regions are attractive for migration of Ukrainians. These include: Moscow, Saint Petersburg with its regions (Moscow and Leningrad), and the following regions of the so-called "Warm Russia" (Voronezh and Belgorod regions and Krasnodar Krai) and Tyumen region [22]. Consequently, the growth rate of the indicator "the commissioning of residential buildings per capita, sq. m. of total area" is one of the important attracting factors for migration of Ukrainians, whose housing preferences tend towards comfortable apartments in large cities or economically developed regions with a warm climate, to Russia.

\section{CONCLUSIONS}

The study revealed the role of post-Soviet countries, namely Armenia, Kazakhstan, Kyrgyzstan, Tajikistan, Uzbekistan, and Ukraine in the migration processes of the Russian Federation.

The impact of the COVID-19 pandemic on the migration exchange of the Russian Federation with the post-Soviet countries is considered: we revealed the decrease in the number of arrivals and the increase in the number of citizens leaving the country, and, consequently, a significant decrease in the migration growth of the Russian population in exchange with the studied countries.

It was confirmed that the most important factor in the country's migration attractiveness is its economic development in comparison with other countries. However, the indicators of economic development as factors of migration attractiveness differ for individual countries.

According to the results of the correlation analysis, for Russia such factors as socio-economic indicators as gross agricultural output per capita and the cost of living are attracting migration factors for the period from 2010 to 2020 .

It should be noted that the indicator of gross agricultural output per capita is an attractive factor for the population of Kyrgyzstan and Uzbekistan to Russia. And the indicator "the value of the subsistence minimum, US dollars" is an attractive factor for the population of Armenia, Kyrgyzstan and Uzbekistan.

Also, for such countries as Armenia, Kyrgyzstan, and Uzbekistan, the following socio-economic indicators are attracting factors of population migration to Russia: foreign trade turnover in US dollars; export per capita in US dollars; imports per capita in US dollars; investments in fixed assets per capita in US dollars. And for the population of Armenia, Kyrgyzstan such factor is growth of GDP per capita in US dollars.

For the population of Kazakhstan, an attractive factor for migration to Russia is the increase in the level of employment in Russia.

For the population of Tajikistan, the main factor is the increase in the ratio of the average pension size and the subsistence minimum in US dollars, as well as the ratio of the average monthly nominal salary and the subsistence minimum in US dollars.

For the population of Ukraine, the main factor is growth of socio-economic indicators: import of Russia as a percentage to GDP; commissioning of residential buildings per capita (sq. m. of total area). 
Pushing factors for population migration to Russia from the studied countries for the period 2010-2020 appeared to be the following ones:

1. For Armenia and Uzbekistan it is the increase in the average annual exchange rate of the US dollar against the national currency (Russian Ruble);

2. For Kazakhstan it is import growth of Russia as a percentage to GDP.

At the end of our article, we emphasize that when developing measures in the field of migration policy of the Russian Federation, the authorities need to take into account the attracting and pushing factors identified in the study. This will help attract the necessary labor force, reduce the outflow of the working-age population from the country, preserve the intellectual potential of society, and ensure the sustainable development of the Russian Federation.

\section{REFERENCES}

[1] Report of the International Commission on Environment and Development "Our Common Future"

https://www.un.org/ru/ga/pdf/brundtland.pdf

[2] Transforming Our World: The 2030 Agenda for Sustainable Development: Resolution by the UN General Assembly, 2015, https:/unctad.org/system/files/officialdocument/ares70d1_ru.pdf

[3] A. Quinn, E. Pismennaya, Shrinking Labor Force Weighs on Russia's Economic Recovery, Bloomberg, 2021, https://www.bloomberg.com/news/articles/202111-16/shrinking-labor-forces-weighs-on-russiaand-putin-s-economic-recovery

[4] E. Lee, A Theory of Migration, Demography. No. 3 (1966) pp. 47-57.

[5] E.S. Vakulenko, N.V. Mkrtchyan, K.K. Furmanov, Interregional migration in Russia: modeling the relationship with socio-economic indicators and the influence of the distance factor. M.: HSE, 2012, pp. 334-338.

[6] E. Fong, K. Shibuya, X.Chen, Migration among East and Southeast Asian Economies, International migration, 2019, pp. 1-16. DOI: https://doi.org/10.1111/imig.12653.

[7] Yu.A. Logunova, Socio-economic consequences of international population migration, Scientific and methodological electronic journal Concept, 10 (2018) pp. 250-255.

[8] R. Ramos, Migration aspirations among youth in the Middle East and North Africa region, Journal of Geographical Systems, 21(4) (2019) pp. 487507. DOI: https://doi.org/10.1007/s10109-01900306-1.

[9] S.V. Taskaeva, Factors determining population migration, Tomsk State University Journal. Transbaikal state. University, 3. (2007) pp. 174179.

[10] A.A. Tkachenko, A.B. Ginoyan, Assessment of the migration potential of the CIS countries on the basis of the international migration model, Statistics Issues, 11 (2018) pp. 46-56.

[11] P.G. Abdulmanapov Factors and consequences of international population migration, UEPS: Management, Economics, Politics, Sociology, 1 (2019) pp. 51-57.

[12] R. Bhagat, Population and Sustainable Development International journal of global environmental issues, 11(3/4) (2011) pp. 197-199. https://www.researchgate.net/publication/2341694 86_Population_and_Sustainable_Development.

[13] V.I. Perevedentsev, Methods for studying population migration. Moscow: Nauka, 1975. pp.107-108.

[14] G.S. Vechkanov, Migration of labour resources in the USSR. - L., 1981.

[15] The official website Statistics Committee of the Ministry of National Economy of the Republic of Kazakhstan (2020), http://stat.gov.kz.

[16] The official website of the Federal Statistics Service of the Russian Federation (2020), https://www.gks.ru.

[17] B. Doskalieva, Features of employment of the population of Kazakhstan in the context of global trends, Bulletin of Kyiv National University named after Taras Shevchenko. Series: Economics. 142, (2012) pp. 16-20. https://cyberleninka.ru/article/n/osobennostizanyatosti-naseleniya-kazahstana-v-kontekstemirovyh-trendov.

[18] O.S. Polenova, A.V. Korostova, The impact of Ruble devaluation on the activities of major exporters and importers in the Russian Federation Scythian. Student science issues, 5-2(45) (2020) pp.56-61. https://cyberleninka.ru/article/n/vliyaniedevalvatsii-rublya-na-deyatelnost-krupneyshiheksportyorov-i-importerov-v-rossiyskoy-federatsii

[19] B.M. Torogeldieva, Migration of Kyrgyz citizens to Russia: opportunities and Risks. 4(22), (2020) pp.67-72.

https://cyberleninka.ru/article/n/migratsiya- 
kyrgyzskih-grazhdan-v-rossiyu-vozmozhnosti-iriski

[20] E.V. Reprintseva, On the ratio of nominal wages to the subsistence minimum in Russia, Economic research. 2 (2019). https://cyberleninka.ru/article/n/o-sootnosheniinominalnoy-zarabotnoy-platy-i-prozhitochnogominimuma-v-rossii

[21] On housing construction in the Russian Federation in 2020. https://rosstat.gov.ru/storage/mediabank/Vlz36soX/ jil-str_2020.pdf.

[22] N.A. Rozinskaya, I.A. Rozinsky, Ukrainian migration to Russia: results and prospects, Economic policy. 4 (2020) pp. 88-109. https://cyberleninka.ru/article/n/ukrainskayamigratsiya-v-rossiyu-itogi-i-perspektivy 